\title{
THE EFFECT OF EPINEPHRIN ON THE PARTITION OF FOOD STUFFS IN OBESE AND NORMAL INDIVIDUALS
}

By CLEMENT I. KRANTZ AND JAMES H. MEANS

(From the Metabolism Laboratory of the Massachusetts General Hospital, Boston, Massachusetts)

(Received for publication February 10, 1927)

In a recent report (1), we have shown that the characteristic rise in the total metabolism, pulmonary ventilation and pulse pressure, caused by the injection of a small amount of epinephrin, ${ }^{1}$ is not significantly different in obese and normal individuals. The respiratory quotient, on the other hand rises definitely less in the obese persons than in the normal subjects. This difference suggests that the obese oxidize a relatively greater amount of fat after epinephrin injection than do normal individuals. The interpretation of the respiratory quotient in terms of percentages of food stuffs burned, therefore, should throw some light on the metabolic processes of these two types, where the conditions of the experiment have been constant. In this report we have endeavored to interpret these respiratory quotients in such manner and have also studied the effect of epinephrin injection on the partition of protein, fat and carbohydrate in obese and normal subjects. The data from which the respiratory quotients were derived appeared in our previous paper (1), while new observations on protein metabolism are given below. We will first consider the effect of epinephrin injection on protein metabolism as shown by study of the urinary nitrogen excretion.

\section{EFFECT OF EPINEPHRIN UPON PROTEIN METABOLISM}

Since Blum (2) in 1901 first described glycosuria resulting from epinephrin injection many investigators have studied the action of epinephrin and have endeavored to interpret and explain its effect,

${ }^{1}$ The amount of epinephrin injected was $0.625 \mathrm{mgm}$. of Parke, Davis and Company tablet "Adrenalin." 
not only upon carbohydrate metabolism, but also upon protein and fat metabolism. In a second paper (3) Blum found that glycosuria would eventually cease after repeated epinephrin injection, but also that it would reappear when olive oil was given. He believed this was due to the glycerin component of the olive oil, but he did not believe body protein was entirely spared in the production of the resulting glycosuria. This would presuppose an increased nitrogen excretion. Paton (4) agreed with Blum and reported an increased ammonia nitrogen excretion at the expense of the urea nitrogen, so that the total nitrogen excretion was not increased. This was emphatically denied by Underhill and Closson (5), who found no change in the distribution of nitrogen in the urine of their experimental animals before and after epinephrin injection. Eppinger, Falta and Rudinger (6) however, found that epinephrin caused an increased protein metabolism. Allen (7) reviewed and summarized the investigations of workers in this field and concluded that: "Since there are so many negative results, adrenalin has no direct influence upon protein metabolism. The positive results may be explained by local tissue necrosis, fever, sweeping out of nitrogen by diuresis and possibly by formation of carbohydrate from protein."

Roubitschek (8) studied the same problem and believed that nitrogen excretion was increased only in those dogs having a positive nitrogen balance. In starving dogs there was no significant increase in the nitrogen excretion after epinephrin injection. The French investigators have gotten varying results. Brel (9) found no increase in nitrogen production in fasting and normally fed rabbits. Marie (10) reported an increase in blood urea after injecting epinephrin intravenously in rabbits, while Bru (11) found a characteristic increase of oxygen consumption, though no change was demonstrable in the nitrogen exchange after giving epinephrin subcutaneously to dogs. A temporary rise followed by a continuous high excretion of nitrogen on the day following epinephrin injection was reported by Allan, Dickson and Markowitz (12). Palladin and Tichwinskaja (13) varied the amount of epinephrin injection and found that $0.5 \mathrm{mgm}$. given once daily caused no rise in the nitrogen output, while if the amount was increased, a rise in the total nitrogen and creatinin excretion followed. Lately Junkersdorf and Török (14) have studied 
the nitrogen metabolism as well as other factors in fasting dogs, before and after the injection of epinephrin, and they have reported an increase in the urinary nitrogen during the epinephrin period.

From the above it can readily be seen that the results are somewhat conflicting. In general, the work of Palladin and Tichwinskaja seems to offer the most satisfactory solution, for where an increased nitrogen excretion was found, the amount of epinephrin injected was usually in excess of $1 \mathrm{mgm}$. On the other hand, in those cases where

TABLE 1

Total urinary nitrogen excretion

\begin{tabular}{|c|c|c|c|c|c|c|c|c|}
\hline \multirow{2}{*}{ Name } & \multicolumn{2}{|c|}{$\begin{array}{l}\text { Before } \\
\text { epinephrin } \\
\text { injection }\end{array}$} & \multicolumn{6}{|c|}{ After epinephrin injection } \\
\hline & $\left|\begin{array}{c}0 \text { to } 30 \\
\text { minutes }\end{array}\right|$ & $\begin{array}{l}30 \text { to } 60 \\
\text { minutes }\end{array}$ & $\begin{array}{l}9 \text { to } 30 \\
\text { minutes }\end{array}$ & 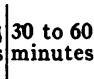 & $\begin{array}{l}60 \text { tc } 90 \\
\text { minutes }\end{array}$ & $\mid \begin{array}{c}90 \text { to } \\
120 \\
\text { minutes }\end{array}$ & $\left|\begin{array}{c}120 \text { to } \\
150 \\
\text { minutes }\end{array}\right|$ & $\begin{array}{c}150 \text { to } \\
180 \\
\text { minutes }\end{array}$ \\
\hline & $m g m$. & mgm. & $m g m$. & $m g m$. & $m g m$. & $m g m$. & $m g m$. & $m g m$. \\
\hline G. $0 \ldots \ldots \ldots \ldots \ldots \ldots \ldots$ & 423 & 538 & 411 & 420 & 417 & 544 & $166^{*}$ & $274^{*}$ \\
\hline M. K................. & 172 & 133 & 202 & 121 & 135 & 122 & 116 & 111 \\
\hline M. T... & 149 & 104 & 147 & 133 & 70 & 92 & 103 & $166 \dagger$ \\
\hline A. F ..... & 156 & 236 & 244 & 223 & 215 & 280 & 224 & 169 \\
\hline K. P $\ldots \ldots \ldots \ldots \ldots$ & 289 & 289 & 160 & 146 & 191 & 172 & 140 & 168 \\
\hline L. J................... & 143 & 287 & 246 & 268 & 215 & 223 & 210 & 176 \\
\hline Average........... & 222 & 264 & 235 & 219 & 207 & 239 & 160 & 177 \\
\hline
\end{tabular}

* Subject G. O. became nauseated during these two periods. He drank no more water during this time and his urine output dropped markedly. This perhaps accounts for his low nitrogen excretion during these two periods.

$\dagger$ The urine output of subject $M$. T. was greatly increased during this period, probably accounting for the increased nitrogen excretion.

no increased output of nitrogen was demonstrable, the amount was generally less than $1 \mathrm{mgm}$.

\section{EXPERIMENTAL}

The majority of the experiments upon the effect of epinephrin on protein metabolism have been carried out on dogs. Therefore, to see if any such action existed in the normal human individual, six apparently well persons were given $0.625 \mathrm{mgm}$. of epinephrin intramuscularly. Each subject was studied in the resting, post-absorptive 
condition. Urine collections were made at half hourly intervals and to assure a sufficient and constant quantity of urine during these short periods, the subjects were given a glass of water to drink at the beginning of each period. For purposes of control, collections were made for two half hour periods before epinephrin was injected. The results are tabulated in table 1.

The average figures show no significant variation either before or after epinephrin injection, except during the last two periods, when other factors, such as nausea caused a diminution in the water intake. The amount of urine excreted was therefore less and the total nitrogen output fell, probably because of the change in sweeping out of nitrogen from the tissues by lessened diuresis. From our findings we may conclude that injections of small amounts of epinephrin have no significant influence upon protein metabolism.

EFFECT OF EPINEPHRIN UPON FAT AND CARBOHYDRATE METABOLISM

In his monograph on metabolism, DuBois (15) states that, fourteen hours after his last meal, a normal individual derives approximately 15 per cent of his calories from protein. This introduces an error of less than 1 per cent in the calculation of metabolism. In order, therefore to interpret the respiratory quotients in terms of fat and carbohydrate burned, we have assumed that 15 per cent of the calories were obtained from protein. Moreover, since the injection of epinephrin in the dosage employed produces no significant effect on protein metabolism, we have also assumed that 15 per cent of the calories were obtained from protein throughout the experiments. The remaining 85 per cent of the calories were derived, therefore, from fat and carbohydrate. With the aid of DuBois' chart (15) we have derived the per cent of fat and carbohydrate burned during the various periods before and after epinephrin injection. The individual and average respiratory quotients of the obese and normal subjects are given in tables 2 and 3, and the average values of these respiratory quotients interpreted in the above manner are shown graphically in charts 1 and 2.

On first glance at these charts, it will be seen that the obese subjects metabolize more fat than do the normal individuals during corresponding periods of time. In the control periods, that is, before 
the injection of epinephrin, the obese used up several times as much fat as carbohydrate, while the normal subjects burned up approximately equal amounts of each. But during the first period after epinephrin was given, the obese subjects used only equal amounts of fat and carbohydrate, which condition was obtained in the normals during the preinjection period. On the other hand, the normal sub-

TABLE 2

Respiratory quotients-obese subjects

\begin{tabular}{|c|c|c|c|c|c|c|c|c|c|}
\hline \multirow{2}{*}{ Name } & \multicolumn{2}{|c|}{ Basal } & \multicolumn{7}{|c|}{ After epinephrin injection } \\
\hline & 1 & 2 & $\begin{array}{c}10 \\
\text { minutes }\end{array}$ & $\begin{array}{c}20 \\
\text { minutes }\end{array}$ & $\begin{array}{c}30 \\
\text { minutes }\end{array}$ & minutes & $\begin{array}{c}90 \\
\text { minutes }\end{array}$ & $\begin{array}{c}120 \\
\text { minutes }\end{array}$ & $\begin{array}{c}150 \\
\text { minutes }\end{array}$ \\
\hline N. C. . & 0.79 & 0.75 & 0.81 & 0.79 & 0.85 & 0.81 & 0.78 & 0.77 & 0.74 \\
\hline L. V..... & 0.70 & 0.72 & 0.83 & 0.78 & 0.80 & 0.76 & 0.73 & 0.71 & 0.73 \\
\hline H. С..... & 0.75 & 0.78 & 0.80 & 0.78 & 0.78 & 0.79 & 0.74 & 0.75 & 0.71 \\
\hline M. P... & 0.88 & 0.79 & 0.88 & 0.85 & 0.81 & 0.76 & 0.81 & 0.88 & 0.82 \\
\hline M. R... & 0.74 & 0.72 & 0.82 & 0.79 & 0.80 & & 0.73 & 0.74 & 0.75 \\
\hline D. A... & 0.81 & 0.81 & 0.92 & 0.81 & 0.77 & 0.83 & 0.76 & 0.78 & 0.80 \\
\hline R. P $\ldots \ldots \ldots \ldots \ldots$ & 0.77 & 0.75 & 0.79 & 0.75 & 0.82 & 0.74 & 0.72 & 0.70 & 0.73 \\
\hline Average.......... & 0.78 & 0.76 & 0.84 & 0.79 & 0.80 & 0.78 & 0.75 & 0.76 & 0.75 \\
\hline
\end{tabular}

TABLE 3

Respiratory quotients-normal subjects

\begin{tabular}{|c|c|c|c|c|c|c|c|c|c|}
\hline \multirow{2}{*}{ Name } & \multicolumn{2}{|c|}{ Basal } & \multicolumn{7}{|c|}{ After epinephrin injection } \\
\hline & 1 & 2 & $\begin{array}{c}10 \\
\text { minutes }\end{array}$ & $\begin{array}{c}20 \\
\text { minutes }\end{array}$ & $\begin{array}{c}30 \\
\text { minutes }\end{array}$ & $\begin{array}{c}60 \\
\text { minutes }\end{array}$ & minutes & $\begin{array}{c}120 \\
\text { minutes }\end{array}$ & $\begin{array}{c}150 \\
\text { minutes }\end{array}$ \\
\hline J. G...... & 0.86 & 0.77 & 0.91 & 0.79 & 0.80 & 0.75 & 0.77 & & \\
\hline J. C...... & 0.88 & 0.80 & 0.93 & 0.93 & 0.92 & 0.90 & 0.87 & 0.87 & 0.80 \\
\hline W. B........ & 0.76 & 0.87 & 1.01 & 0.95 & 0.88 & 0.81 & 0.80 & 0.84 & 0.84 \\
\hline H. H.......... & 0.81 & 0.82 & 0.88 & 0.91 & 0.91 & 0.83 & 0.87 & 0.82 & 0.78 \\
\hline Average....... & 0.83 & 0.82 & 0.93 & 0.89 & 0.88 & 0.82 & 0.83 & 0.84 & 0.81 \\
\hline
\end{tabular}

jects metabolized 75 per cent of carbohydrate and only a minimal amount of fat at the end of the first 10-minute period. The difference, thus, is quite striking. In both the obese and normal subjects the comparative amounts of fat and carbohydrate used resumed the pre-injection level at the end of 60 minutes.

That epinephrin reduces the available glycogen supply in the liver 
230 EFFECT OF EPINEPHRIN ON PARTITION OF FOOD STUFFS

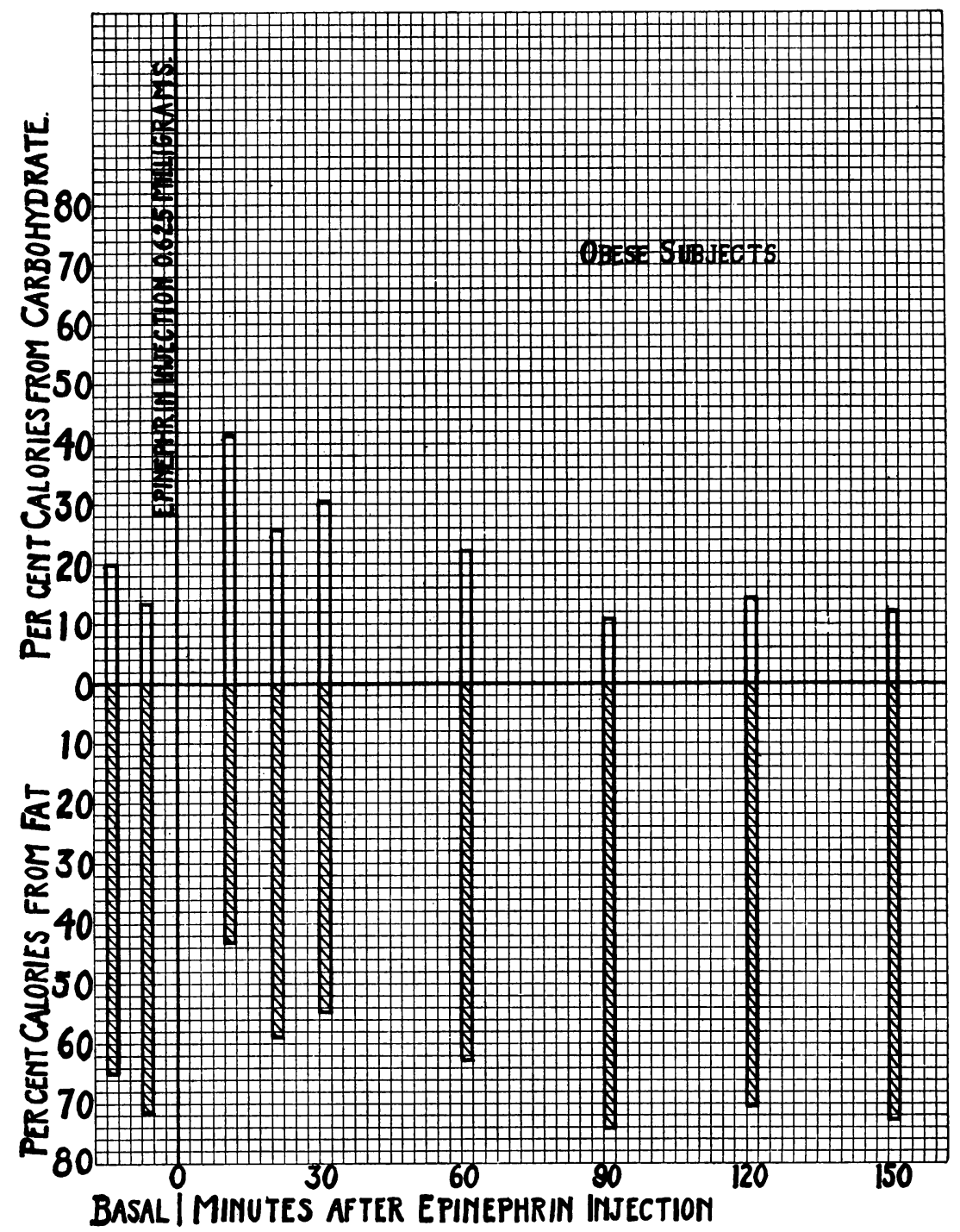

Chart 1. Per Cent Calories Derived from Carbohydrate and Fat after EPINEPHRIN INJECTION-OBESE SUbJECTS 


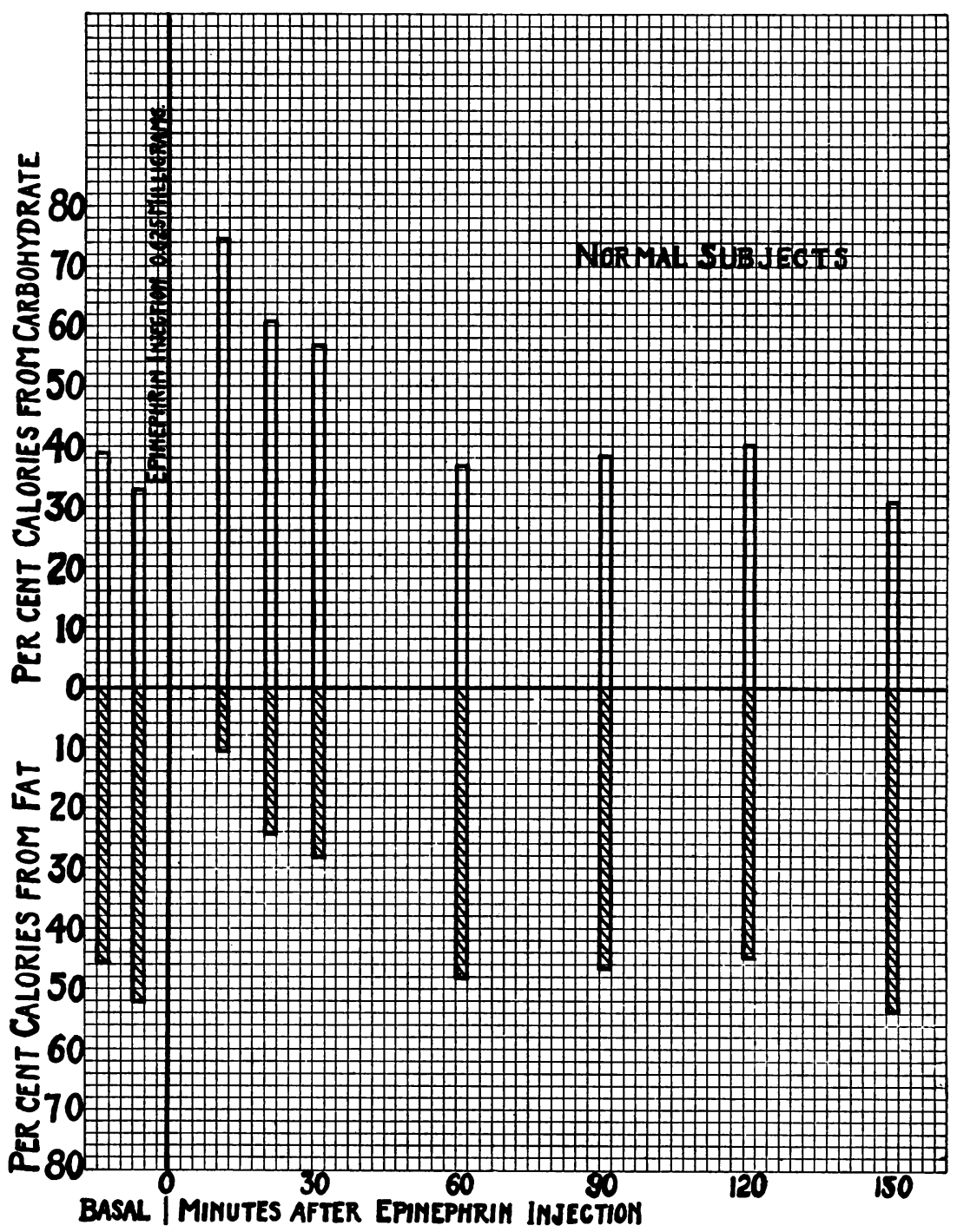

Chart 2. Per Cent Calories Derived from Carbohydrate and Fat after EPINEPHRIN INJECTION-NORMAL SUBJECTS 
is a well known fact (16) (17) (18). According to Geelmuyden (19) fat replaces the liver glycogen when this rapidly disappears as the result of some altered condition. From our experiments, the obese individuals continuously metabolized more fat than carbohydrate, except during the 10-minute period following epinephrin injection, when equal amounts of each were used. On the other hand, the normal subjects responded to epinephrin with an increased carbohydrate metabolism, which outbalanced the fat metabolism during the period of epinephrin effect. Thus it would seem that the glycogen supply of the obese was limited when metabolism was stimulated by epinephrin. Just what causes a decrease in glycogen storage and a corresponding increase in fat deposition in obese persons is not clear.

\section{CONCLUSIONS}

1. The injection of $0.625 \mathrm{mgm}$. of epinephrin produces no significant increase in protein metabolism in normal persons.

2. Our experiments tend to show that obese individuals have less glycogen and more fat available for metabolism.

3. When a metabolic stimulant, such as epinephrin is given, the most readily available food stuff is oxidized and in the case of the obese individuals, this is fat.

\section{BIBLIOGRAPHY}

1. Krantz, C. I., and Means, J. H., Jour. Clin. Invest., 1927, iii, 565. Epinephrin Reaction in Obesity.

2. Blum, F., Deutsch. Arch. f. klin. Med., 1901, lxxi, 146. Ueber Nebennierendiabetes.

3. Blum, F., Arch. f. d. ges. Physiol., 1902, xc, 617. Weitere Mittheilungen zur Lehre von dem Nebennierendiabetes.

4. Paton, D. Noel, Jour. Physiol., 1903, xxix, 286. On the Nature of Adrenalin Glycosuria.

5. Underhill, F. P., and Closson, O. E., Amer. Jour. Physiol., 1906, xvii, 42. Adrenalin Glycosuria, and the Influence of Adrenalin upon Nitrogenous Metabolism.

6. Eppinger, H., Falta, W., and Rudinger, C., Ztschr. f. klin. Med., 1908, lxvi, 1. Ueber die Wechselwirkungen der Drüsen mit innerer Sekretion. I Mitteilung.

7. Allen, F. M., Studies Concerning Glycosuria and Diabetes, Boston, W. M. Leonard, 1913, p. 690. 
8. Roubitschek, R., Arch. f. d. ges. Physiol., 1914, clv, 68. Zur Frage der Zuckerbildung aus Fett.

9. Brel, J., Compt. rend. Soc. de biol., 1921, lxxxv, 1057. Modifications expérimentales de la répartition de l'azote urinaire par injection sous-cutanée d'adrenaline.

10. Marie, A., Compt. rend. Soc. de biol., 1922, lxxxvi, 772. Dosage de l'urée dans différents sérums.

11. Bru, P., Compt. rend. Soc. de biol., 1922, lxxxvi, 1068. Action de l'adrénaline sur les échanges respiratoires et azotés des 24 heures. Importance de la voie d'administration.

12. Allan, F. N., Dickson, B. R., and Markowitz, J., Amer. Jour. Physiol., 1924, lxx, 333. The Relationship of Phosphate and Carbohydrate Metabolism. II. The Effect of Adrenalin and Phloridzin on the Excretion of Phosphate.

13. Palladin, A., and Tichwinskaja, W., Arch. f. d. ges. Physiol., 1925, ccx, 436. Zur Frage der Wirkung des Adrenalins auf die Stickstoff-, Kreatininund Kreatinausscheidung:

14. Junkersdorf, P., and Török, P., Arch. f. d. ges. Physiol., 1926, ccxi, 414. Tierexperimentelle Untersuchungen über die stoffwechselphysiologische Wirkung bestimmter Hormone. I. Die Wirkung des Adrenalins im Hungerzustande.

15. DuBois, E. F., Basal Metabolism in Health and Disease, Philadelphia, Lea \& Febiger, 1924, p. 38-42.

16. Doyon, M., and Kareff, N., Compt. rend. Soc. de biol., 1904, lvi, 66. Action de l'adrénaline sur le glycogène du foie.

17. Gatin-Gruzewska, Z., Compt. rend. Acad. d. sc., 1906, cxlii, 1165. Action de l'adrénaline sur la teneur du muscle en glycogène.

18. Agadschanianz, K., Biochem. Zeitschr., 1907, ii, 148. Über den Einfluss des Adrenalins auf das in Leber und Muskeln enhaltene Glycogen.

19. Geelmuyden, H. C., Ergebn. d. Physiol.: 1923, xxi, 274. Die Neubildung von Kohlenhydrat im Tierkörper. I. Das Syndrom der Fettwanderung und Ketonurie. 